
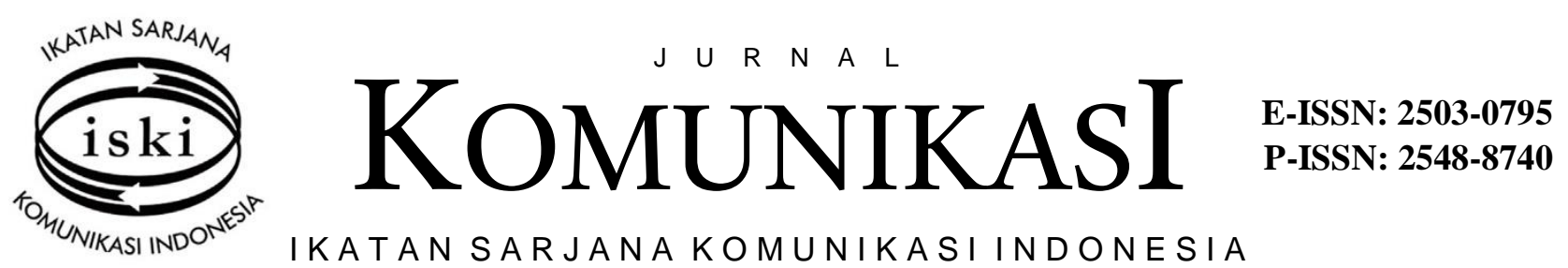

IKATAN SARJANAKOMUNIKASI INDONESIA

\title{
Political Advertising Camouflage as News
}

\author{
http://dx.doi.org/10.25008/jkiski.v3i2.219
}

\author{
Camelia Catharina Pasandaran ${ }^{1 *}$ \\ ${ }^{1}$ Journalism Department of Faculty of Communication, Universitas Multimedia Nusantara \\ Jl. Scientia Boulevard, Gading Serpong, Tangerang - Indonesia \\ ${ }^{1 *}$ Correspondent author: camelia.pasandaran@umn.ac.id
}

Submitted: 25 December 2018, Revised: 26 December 2018, Accepted: 27 December 2018

Accredited by Kemristekdikti No. 30/E/KPT/2018

\begin{abstract}
Advanced technology has significantly influenced media and their environment, including their audience and advertisers. The changes have forced the media to rethink their business model. Native advertising, undisruptive advertising that looks like the original content of the media, is one of the new advertising forms developed in the past few years. This trend started in Indonesia in 2014 as some big online media offer the native advertising space to the advertisers. In the perspective of Baudrillard's postmodern view, this is a kind of simulation which may lead to the death of the reality. This study seeks to find the way news simulation work in Indonesian online media advertising. The result shows that the packaging, the placement, and the minimum disclosure of political native advertising have blurred the separation between commercial and editorial content. Analyzing from Baudrillard's perspective, this news simulation is at the second stage of simulation, or evil appearance, in which people can no longer differentiate between the real news and the advertising which simulate the news.
\end{abstract}

Keywords: Native Advertising, Online Media, Baudrillard, Simulation, Simulacra

\begin{abstract}
Abstrak
Kemajuan teknologi telah secara signifikan mempengaruhi media dan lingkungan di mana media berada, termasuk khalayak dan pengiklan. Perubahan yang ditimbulkannya memaksa media untuk memikirkan ulang bisnis model mereka. Native advertising, bentuk iklan yang dibuat untuk meminimalisir gangguan terhadap kenyamanan pembaca karena bentuknya yang seperti konten editorial media, adalah salah satu bentuk iklan yang baru berkembang dalam beberapa tahun terakhir. Tren ini dimulai di Indonesia sekitar tahun 2014 dengan beberapa media online besar menyediakan ruang untuk bentuk iklan ini. Dalam perspektif postmodern Baudrillard, ini adalah bentuk simulasi yang bisa berujung pada kematian realitas. Studi ini berupaya menggambarkan kerja simulasi berita dalam iklan media online di Indonesia. Hasil menunjukkan bahwa pengemasan, penempatan, dan minimnya disclosure dari native advertising politik telah mengaburkan batas antara konten komersial dan editorial. Bila dilihat dari perspektif Baudrillard, simulasi berita ini berada pada tahap kedua dari simulasi, atau evil appearance, di mana khalayak tidak lagi bisa membedakan antara berita yang nyata dan iklan yang mensimulasikan berita.
\end{abstract}

Kaka kunci: Native Advertising, Media Online, Baudrillard, Simulasi, Simulakra

Copyright @ 2018 Ikatan Sarjana Komunikasi Indonesia. All rights reserved 


\section{Introduction}

The advancement of computer-based technology has significantly changed the media landscape in Indonesia. At least, it changes the media environment in three aspects, its audience, content, and source of revenue. Concerning the audience, advanced technology leads them to consume news online especially those who live in metropolitan cities. They are characterized by their reluctance to pay for the content and their demand to get news as soon as possible. Most online media provide content for free. Some foreign media successfully apply the paywall system, but in Indonesia, similar effort has not been fruitful. Few media, including the Jakarta Post, Tempo magazine and Kompas, are among those which implement such system to no significant avail.

Aside of preference for free content, today's audience is characterized by their ads avoidance behavior. McCoy et al. (2004) said that pop-up, popunder, and in-line ads have been said to be intrusive and could have affected user perception. Their findings concluded that the mere existence of ads decreases the retention of both site and ad content. Pop-up ads were said to be more intrusive in compare to in-line ads. McCoy et al suggested that their research implied that users should not be interrupted from their online activities to close the ads windows.

The technological development also leads the media to shift their focus to digital media. Since the late 1990s, both printed and electronic media started to publish their content online and a decade later, started newsroom convergence with multimedia content as their products. Nielsen research published in December 2017 shows the growth of online media readership. The research reveals the number of online media readers has reached six million, while print media readers decline to 4.5 million.

However, the sharp increase of readership does not go in line with the revenue. According to the Australian advertising agency Big Mobile, digital ads buying in Indonesia is only 17 percent of the total ads spending, or 2.8 million dollars (Adam, 2018). A combination of the way people consume the news, their reluctance to pay for the content, ads avoidance behavior, has forced media to find a new business model.

Nowadays, native advertising is seen as one of the new ways to get revenue. While the practice of native advertising is not really new, the term itself has only been around in the past few years. Quoting DiFilippo, Smith (2017) said that native advertising has always been there, but the term is relatively new.
BuzzFeed and New York Times were said to be among the first to introduce native advertising. The latter first native ads is Dell with Orange is the New Black.

There are numerous definitions of native advertising. Ferrer Conill (2016) defines native advertising as "a form of paid content marketing, where the commercial content is delivered adopting the form and function of editorial content with the attempt to recreate the user experience of reading news instead of advertising content." Dan Greenberg, the CEO of ads agency Sharethrough and the one who coined the term, said that native advertising is "a form of paid media that follows the form and function of the site or user experience that it lives within." His definition is adopted as the official native advertising guideline that was published by Interactive Advertising Bureau in United States in 2013 (Smith, 2017). Basically, there are two characteristics that can describe native advertising from various definitions available: the adaptation of editorial content format and user uninterruptive experience.

In Indonesia, native advertising has been widely adopted by several online media, including Tempo.co, Detik.com, Merdeka.com, Liputan6.com, and Republika. They apply different forms of native advertising and different ways of disclosing it. Aside of commercial product ads, these media also get political institutions as their clients, such as the Indonesian House of Representatives (DPR), People's Consultative Assembly (MPR), Regional Representatives Council (DPD), political parties, and individual clients who usually were running in the regional election.

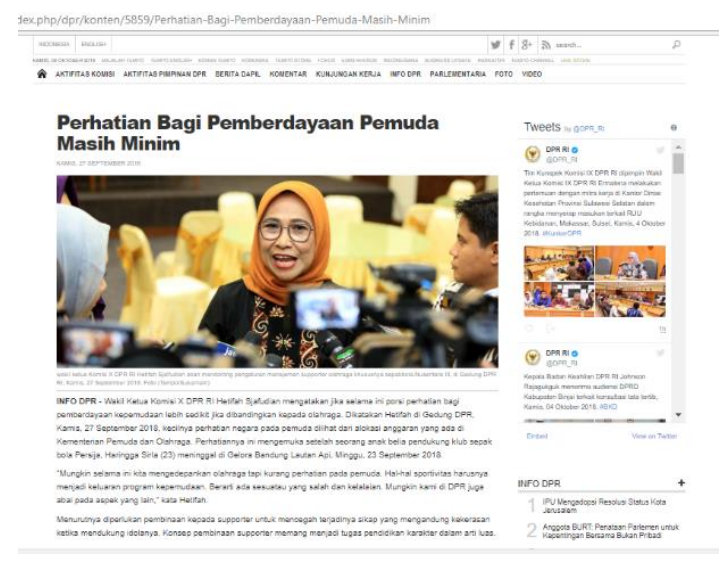

Picture 1. Native advertising of the House of Representatives (DPR) on Tempo.co

Source: Tempo.co 
There have been numerous studies on native advertising. In a positive stance, native advertising is seen as an effective vehicle to reach the audience and positively contribute to sustain the media. However, most researchers criticize native advertising, placing their main concern on the controversy over the ads minimum disclosure.

There are four points of critics from scholars studying native advertising. First and the most criticism toward native advertising came from the fact that media did not provide adequate sponsorship transparency. While the purpose of native advertising is to prevent disruption in consuming news, it doesn't justify the low to no disclosure. A research conducted by Campbell and Evans (2018) shows that the placement of accompanying banner ads help people to recognize native advertising.

The minimum disclosure leads to the second problem: audience -- who failed to recognize the advertising - think of native advertising as editorial content. Many experimental researches on native advertising show the low ability of people to spot the ads. According to Amazeen and Wojdynski (2018), those researches consistently show only small number of participants could recognize the advertising. A research by Wojdynski and Evans (2016) shows a quite striking finding as only eight percent of the 242 participants involved in their experimental study recognized native advertising.

Researches (Amazeen \& Wojdynski, 2018; Howe \& Teufel, 2014) also show that the ability to spot the ads is affected by age and education, with younger and educated people have better odds in recognizing the ads. The presence of sponsor label is reportedly failed to get the attention of the readers. Instead of considering it as advertising label, people tend to consider the $\log o$ as stand alone advertisement (Wojdynski, 2016).

The minimum to no disclosure of the native advertising leads to the third problem: the falling credibility of the media, advertisers, and content. $\mathrm{Wu}$ et al. (2016) claimed that media put their credibility at stake by publishing such advertising. This claim is in line with the research of Amazeen and Muddiman (2018) that shows declining media credibility when people recognize the ads. Another research by Iversen and Knudsen (2017) revealed that explicit label of political native advertising could lead to decreasing trust toward political news content. Not all researches consistently show that native advertising has negative influence on media credibility, content, and advertisers. Based on the result of their research, Krouwer, Poels, and
Paulussen (2017) claimed that native advertising had no influence on credibility. Similar result also shown by a research conducted by Lee, Kim, and Ham (2016) which pointed out that there was no significant negative response toward native advertising. Therefore, they suggested advertisers to focus on the positive side of native advertising rather than considering that they had mislead the audience.

The fourth problem related to native advertising is the falling editorial firewall. However, integration between editorial and business department of media has been seen inevitable. A research by Cornia et al. (2018) titled "We no longer live in the time of separation" shows the trend of new norms called integrative or collaborative norms.

The purpose of the present study is to descriptively reveal the form, the placement, and the disclosure method of political native advertising. This has become an important issue because many of Indonesian online media tend to provide no clear disclosure which potentially mislead readers.

Tempo is selected as the object of the study because of its prominence as the leading investigative media in Indonesia. One of Tempo's native advertising client is the Indonesian House of Representatives. This media puts the content in a specific microsite with the url of dpr.tempo.co

\section{Theoretical Framework}

This research will use Baudrillard's simulation theory to analyze the way media simulate news article in their native advertising content and explore the concept of native advertising to analyze its implementation by Indonesian media.

Baudrillard's Simulation. Jean Baudrillard is considered to be a postmodern thinker. His theory of simulation is seen as his entry to postmodernism. To simulate is to feign to have what one doesn't have. To Baudrillard's opinion, simulation threatens the difference of what is true and false, of the real and the imaginary (Baudrillard, 2006). Simulation is different with representation. Representation departs from the principle of similarity with the real. Simulation works as a radical negation of the sign as value, a reversion of sign and death sentence of reference.

The term simulacra is not Baudrillard's original term. Plato used the term to theorize the relationship between reality and significations (Kaneva, 2018). In Baudrillard's conception, the term simulacrum is a sign that bears no relation to reality. 
Simulation occurs in four steps. Firstly, it reflects profound reality or in Baudrillard's term "good appearance", a representation of the sacramental order. Second, it masks and denatures a profound reality or evil appearance. Third, it masks the absence of reality or becomes the appearance itself. In the end, it has no relation to the appearance, it becomes its own pure simulacrum. As this occurs, the real meaning turns into nostalgia (Baudrillard, 2006).

In Baudrillard's other writing titled "Simulacra and Science Fiction", he mentioned three orders of simulacra: natural simulacra, productive simulacra, and simulacra of simulation. Natural simulacra is the imitation of the image that doesn't seek to hide the real. Productive simulacra is founded on energy with the idea of globalization and expansion. The last one, simulacra of simulation, is a hyperreality with the aim of total control.

While the first phase still reflects the reality, at the end no longer it reflects the truth. People can no longer separate the true from the false. The simulacrum has the ability to kill the model that gives it life and replace the reality with its own life. This results in a condition of hyperreality where it is impossible to differentiate between the real image and the simulation.

Hyperreality is caused by capital. Baudrillard said "throughout its history, it was capital that first fed on the destructuration of every referential, of every human objective, that shattered every ideal distinction between true and false, good and evil, in order to establish a radical law of equivalence and exchange, the iron law of its power ... it was also the first to liquidate it (reality) by exterminating all use value, all real equivalence of production and wealth, in the very sense we have of the unreality of the stakes and the omnipotence of manipulation" (Baudrillard, 2006).

Simulation can last because it is an object of social demand. It can kill the reality, but it can no longer subject to death because of the law of supply and demand. Just as commodity, simulation depends on mass production and consumption (Baudrillard, 2006).

Native advertising can be seen as a simulation, advertising that simulates the form of a news article. On top of its resemblance with the news article, some Indonesian media place their native advertising among news article, making it even more difficult for the reader to recognize them as advertising.
Native Advertising. The term native advertising is relatively new, but the practice has been done quite long by media. Quoting McLoughlin, Smith (2017) said that media has done this for long, but "it just became digital". In the past, the "native advertising" was in the format of advertorial and sponsored program on television. The difference between the old and the current practice of native advertising lies on the digital media, which has blurred the distinction between the editorial content and advertising.

Along with the transition to the digital era, some media change the old style of advertorial in the digital format. Buzzfeed was among the first to implement this strategy. It was also one of the first to use this form of advertising for political clients. Obama for America became the first political campaign to advertise on Buzzfeed. The content is similar to Buzzfeed editorial content, but put a label on top of the ads "Paid Political Content" (Ellis, 2012).

In Indonesia, few media have been known to receive political native advertising, including Merdeka.com, Tempo.co, Liputan6, and Republika. Some of them published the stories on a separate microsite, but some of them place the ads in the homepage, along with the real news articles.

With the popularity of digital native advertising, many come up with definitions of such ads. The term itself was coined by Dan Greenberg, CEO of Sharethrough. In his definition, native advertising is "a form of paid media that follows the form and function of the site or user experience that it lives within" (Smith, 2017). The highlight is the format and the audience. It has to resemble the editorial content and it has to be less intrusive than the conventional advertising.

Numerous earlier studies show that there has been deception in the way media present their native advertising as most of the readers failed to recognize them as ads. The Indonesian Advertising Council has published a code of conduct, and one of its points stipulates that media has to reveal the advertiser.

\section{Material and Methodology}

This research focuses on the text analysis of native advertising published on Tempo.co, an investigative media in Indonesia. The analysis is expected to reveal three major things. First, the placement of native advertising on the website. Second, the format of native advertising in an attempt to find similarities and dissimilarities with the original editorial content. The third is to find the 
disclosure of the native advertising. It leads to research questions as below:

RQ 1 : How does Tempo place native advertising content?

RQ 2 : How does Tempo native ads simulate news article?

RQ 3 : How does Tempo disclose its native advertising?

Native advertising of Tempo published in September 2018 were collected and analyzed with qualitative content analysis. Differently with quantitative content analysis, qualitative content analysis examines language intensely to classify text into categories that represent similar meanings. The goal is to provide knowledge and understanding of the phenomenon being studied (Hsieh \& Shannon, 2005).

All native advertising of House of Representatives published by Tempo within September 2018 randomly selected to be analyzed to find the pattern of the ads. For the purpose of this study, native advertising text will be compared based on the structure of a news article. Therefore, the categories include the availability of headline, byline, dateline, photos, lead, nutgraph, quotes, sources, closing.

\section{Result and Discussion}

Placement of native advertising. Tempo published their native advertising on a special sub canal named "inforial", under the canal of "others". In this sub canal, several types of commercial products and information from various clients were published. Here, the native ads are grouped into few categories: recent (ads), most popular, healthy information, automotive information, housing information, business memo information, and hotel agenda information.

Beside being placed under this sub canal, some native advertising were placed on the homepage. It is not known whether there is an additional cost to do this, but other Indonesian media, such as Bisnis.com, charge an additional fee for this placement.

Tempo also has special microsite dedicated for clients which demand a long term contract. One of them is the House of Representatives (DPR). The microsite can be accessed through the URL dpr.tempo.co. This microsite comprises nine sub canals, including commission's activity, speaker's activity, news from the regional election districts, comments, working visit, DPR info, parlementaria, photo, and video. The fact that the sub canal is funded by the House of Representatives has not been clearly revealed.

According to the copywriter of this microsite, who was interviewed in September 2018, the native advertising contents were given by the House of Representatives and from daily coverage. Should she got the press release from the House of Representatives, she rewrote it into an article. Due to her contract with the media, she should publish up to five articles a day on the microsite.

"I selected the content by myself," she said. "I also managed the CMS (content management system). I took two articles from the press release and edit it according to the media style. The rest, I cover the events there."

Native ads design: simulating the news? The design of the native advertising resembles the original news of Tempo.

Table 1. Similarities of Native Advertising to News

\begin{tabular}{|l|l|}
\hline Categories & \multicolumn{1}{c|}{ Availability } \\
\hline Headline & Available, resembling the headline of news in a positive tone \\
\hline Photo & $\begin{array}{l}\text { One photo in each native ads. Some of them were attributed to } \\
\text { the client, some were taken by Tempo photojournalist. }\end{array}$ \\
\hline Byline & None. \\
\hline Dateline & Info \\
\hline Lead & $\begin{array}{l}\text { Available, most of the lead tend to be positive. However, in } \\
\text { some stories, the lead negatively criticize the government }\end{array}$ \\
\hline Nut Graph & Not available \\
\hline Quotes & $\begin{array}{l}\text { Direct quotes available with all of the first quotes were from } \\
\text { member of the House of Representatives }\end{array}$ \\
\hline Sources & $\begin{array}{l}\text { Mostly single source. If there is more than one source, they } \\
\text { were from the same side. Alternative sources were available, } \\
\text { both not from the opposing sides. }\end{array}$ \\
\hline Closing & No specific type of closing \\
\hline
\end{tabular}

Source: Data analysis 
Native advertising mimics most of the characteristic of the news. First, they have headlines just as ordinary news. However, most of the headlines are positive, such as "House of Representatives Approves Budget Limit of the Ministry of Youth and Sport".

Each of native advertising published in Tempo has a photo located below the headline and has a caption below the photo. Some of the photos were attributed to the House of Representatives, while some others were attributed to Tempo photographers. Most of the photos captured events involving parliament members.

None of the native advertising has a byline. In Tempo ordinary articles, the byline comprises the names of the reporter and the editor. None of the ads also has dateline. In the ordinary news articles, the dateline shows the city of the event, but in the native ads, it is replaced with the word "Info + client name". If the client was the House of Representatives, the dateline would be "Info DPR".

The top paragraph of the native advertising simulates the lead of a hard news article, with the $5 \mathrm{~W}+\mathrm{H}$ principle, even though not all of the elements were present in the lead. The tone of the lead tends to be positive or neutral.

The quotes in the native advertising were formulated similarly to an ordinary news article. The top quote comes from the client, which in this case is the parliament members. Each native ads usually has more than a quote, but frequently from the same source.

Ideally, a news story would have a nutgraph that describes why the story is important for the reader to read. This nutgraph is missing in Tempo's native advertising. However, nutgraph is hardly found on the news article of Indonesian online media either.

The main source is the client of the native advertising, or in this case, member of the parliament. If there is more than a source, the latter source is usually also a parliament member which come up with the same concern. Rarely a native ads published on this microsite came from source outside the parliament. There were indeed native advertising with outside sources, such as an economic expert or sports commentator. However, more often than not, they share similar concern with the main source. No specific type of closing found in the native ads published by Tempo.

Disclosure of native advertising. There is a slight chance for readers to recognize the advertising as no clear indicators provided on the native ads page. The indicators to spot native advertising in Tempo are: (1) URL (Uniform Resource Locator). One of the ways to spot native advertising is to see the URL of the page. If it is located in a specially allotted microsite, the URL would be "client.tempo.co", for instance dpr.tempo.co. The other native ads located under inforial.tempo.co. There are numerous clients place their native ads in this sub canal; (2) Dateline. The second method to determine whether a lookalike news is actually a native ad, is to see the dateline. Instead of placing the name of a city, Tempo puts the words "Info + client name" such as INFO BISNIS.

\section{Conclusion}

The placement of Tempo articles in a separate microsite or under specific canal is actually a positive way to separate the news articles from the commercial content. However, some native ads were also placed on the homepage. The word "Info" appears on the native ads featured image on the homepage. This is not a distinctive way to differentiate them from the news article. In Baudrillard's term, instead of "good appearance", this has turned native ads into "evil appearance". People can no longer differentiate between the news and the ads, and easily mislead them as a news article that has gone through verification and editing process to ensure the quality.

Tempo packages native ads similar to an ordinary news article. But, there are still some differences which can be traced from its non-existing byline and "special" dateline. The other differences from the news article are the content of the native ad which tends to positive and the failure to cover both sides. In a controversial story such as criticism toward the government from the House of Representatives, sources from the government were rarely interviewed. Using Baudrillard's four phases of simulation, this differentiation shows the first phase of "good appearance". It resembles news articles, but not totally similar.

The disclosure of the native ads can be found on the url, the non-existing byline, and the special dateline. However, in comparison to the native ads in other countries, this is a minimum type of disclosure. Other foreign media are known to clearly disclose the ads by placing the words "sponsored content", "sponsored post", and "paid content".

Overall, judging from three aspects being studied above - the disclosure, packaging, and 
placement of native advertising - it can be concluded that the simulation is still in the second phase, or evil appearance. At this stage, people can no longer differentiate between the real news and the ads.

As a trend, the number of native advertising has been increasing. The unlimited digital space has paved the way for the possibility of the native ads to outgrow the number of the news articles one day, should the media successfully attract more clients. Eventually, it can lead to the third and fourth stage of simulation, in which the existence of native ads covers the non-existing news. Baudrillard claimed that the cause of this simulation and hyperreality was capitalism. Using the logic of hypercapitalism, media might tend to provide more space for native ads which later might further mislead people into thinking that native ads are the real news. If it reaches the final stage, it will be the end of journalism.

Baudrillard, one of the most radical postmodern thinkers, did not provide any solution to such condition. In his opinion, this inevitably happens in a capitalist society. Most of the current studies exploring this problem from the side of the audience and rarely see it from the perspective of the media. For future study, this phenomena might be assessed from other theories or views and from a macro perspective.

\section{References}

Adam, A. (2018, Februari). Benarkah Bisnis Media Online Tak Secerah Masa Depan Internet? Tirto.Id. Accessed from https://tirto.id/benarkah-bisnis-mediaonline-tak-secerah-masa-depan-internetcEv5 in May, 2018

Amazeen, M. A., \& Muddiman, A. R. (2018). Saving Media or Trading on Trust?: The effects of native advertising on audience perceptions of legacy and online news publishers. Digital Journalism, 6(2), 176-195. https://doi.org/10.1080/21670811.2017.129 3488

Amazeen, M. A., \& Wojdynski, B. W. (2018). The effects of disclosure format on native advertising recognition and audience perceptions of legacy and online news publishers. Journalism: Theory, Practice \& Criticism, 146488491875482. https://doi.org/10.1177/1464884918754829

Baudrillard, J. (2006). Simulacra and Simulation. Michigan: University of Michigan Press.

Campbell, C., \& Evans, N. J. (2018). The Role of a Companion Banner and Sponsorship
Transparency in Recognizing and Evaluating Article-style Native Advertising. Journal of Interactive Marketing, 43, 17-32. https://doi.org/10.1016/j.intmar.2018.02.00 2

Cornia, A., Sehl, A., \& Nielsen, R. K. (2018). 'We no longer live in a time of separation': A comparative analysis of how editorial and commercial integration became a norm. Journalism, $\quad 146488491877991$. https://doi.org/10.1177/1464884918779919

Ellis, J. (2012). BuzzFeed adapts its branded content approach to political advertising, and Obama's in. NiemanLab. Accessed from http://www.niemanlab.org/2012/10/buzzfee d-adapts-its-branded-content-approach-topolitical-advertising-and-obamas-in/ in May 2018

Ferrer Conill, R. (2016). Camouflaging Church as State: An exploratory study of journalism's native advertising. Journalism Studies, 17(7), 904-914. https://doi.org/10.1080/1461670X.2016.116 5138

Howe, P., \& Teufel, B. (2014). Native Advertising and Digital Natives: The Effects of Age and Advertisement Format on News Website Credibility Judgments, 4(1), 14.

Hsieh, H.-F., \& Shannon, S. E. (2005). Three Approaches to Qualitative Content Analysis. Qualitative Health Research, 15(9), 12771288. https://doi.org/10.1177/1049732305276687

Iversen, M. H., \& Knudsen, E. (2017). When politicians go native: The consequences of political native advertising for citizens' trust in news. Journalism: Theory, Practice \& Criticism, 146488491668828. https://doi.org/10.1177/1464884916688289

Kaneva, N. (2018). Simulation nations: Nation brands and Baudrillard's theory of media. European Journal of Cultural Studies, 21(5), 631-648. https://doi.org/10.1177/1367549417751149

Krouwer, S., Poels, K., \& Paulussen, S. (2017). To Disguise or to Disclose? The Influence of Disclosure Recognition and Brand Presence on Readers' Responses Toward Native Advertisements in Online News Media. Journal of Interactive Advertising, 17(2), 124-137.

https://doi.org/10.1080/15252019.2017.138 1579 
Lee, J., Kim, S., \& Ham, C.-D. (2016). A doubleedged sword? Predicting consumers' attitudes toward and sharing intention of native advertising on social media. American Behavioral Scientist, 60(12), 1425-1441.

McCoy, S., Everard, A., Galletta, D., \& Polak, P. (2004). A Study of the Effects of Online Advertising: A Focus on Pop-Up and InLine Ads, 6.

Smith, M. (2017). The Native Advertising Advantage: Build Authentic Content that Revolutionizes Digital Marketing and Drives Revenue Growth. McGraw-Hill Education.

Wojdynski, B. W. (2016). The Deceptiveness of Sponsored News Articles: How Readers Recognize and Perceive Native Advertising. American Behavioral Scientist, 60(12),
1475-1491.

https://doi.org/10.1177/0002764216660140

Wojdynski, B. W., \& Evans, N. J. (2016). Going Native: Effects of Disclosure Position and Language on the Recognition and Evaluation of Online Native Advertising. Journal of Advertising, 45(2), 157-168. https://doi.org/10.1080/00913367.2015.111 5380

Wu, M., Huang, Y., Li, R., Bortree, D. S., Yang, F., Xiao, A., \& Wang, R. (2016). A Tale of Two Sources in Native Advertising: Examining the Effects of Source Credibility and Priming on Content,Organizations, and Media Evaluations. American Behavioral Scientist, 60(12), 1492-1509. https://doi.org/10.1177/0002764216660139 